\title{
Peningkatan Hasil Belajar Bahasa Indonesia Melalui Model Problem Based Learning Berbantuan Media Audio Visual
}

\author{
Sofia Mafaza \\ SD Negeri 01 Glandang \\ sofiamafaza@gmail.com
}

\section{Article History}

received 3/12/2020

revised 17/12/2020

accepted $31 / 12 / 2020$

\begin{abstract}
The purpose of this research was to improve student learning outcomes in Bahasa Indonesia grade V elementary schools with a audio visual media assisted Problem Based Learning (PBL) learning model. The research conducted was a Classroom Action Research (PTK) with three cycles, with each cycle consisting of one meeting. The stages of each cycle are planning, implementing, observing and reflecting. Each meeting is carried out a pre test and post test to determine the progress of students. In the first cycle the students who completed after carrying out the post test were $70 \%$. In the second cycle students who completed after carrying out the post test were $90 \%$. In the third cycle students who completed after carrying out the post test were $100 \%$. These results indicate that the Problem Based Learning (PBL) learning model can improve student learning outcomes, especially grade V Bahasa Indonesia at SD Negeri 01 Glandang academic year 2019/2020.
\end{abstract}

Keywords: learning outcomes, problem based learning, audio visual media, Bahasa Indonesia

\begin{abstract}
Abstrak
Tujuan dari penelitian ini adalah untuk meningkatkan hasil belajar peserta didik pada muatan pelajaran Bahasa Indonesia di sekolah dasar kelas $\mathrm{V}$ dengan model pembelajaran Problem Based Learning berbantuan media audio visual. Penelitian yang dilakukan adalah Penelitian Tindakan Kelas (PTK) sebanyak tiga siklus, dengan setiap siklusnya terdiri dari tiga pertemuan. Tahapan setiap siklusnya adalah perencanaan, pelaksanaan, observasi dan refleksi. Setiap pertemuan dilakukan tes formatif untuk mengetahui perkembangan peserta didik. Pada siklus I peserta didik yang tuntas setelah melaksanakan tes formatif sebesar $70 \%$. Pada siklus II peserta didik yang tuntas setelah melaksanakan tes formatif sebesar $90 \%$. Pada siklus III peserta didik yang tuntas setelah melaksanakan tes formatif sebesar $100 \%$. Hasil ini menunjukkan bahwa model pembelajaran Problem Based Learning (PBL) berbantuan media audio visual dapat meningkatkan hasil belajar peserta didik khususnya muatan pelajaran Bahasa Indonesia Kelas V SD Negeri 01 Glandang Tahun Pelajaran 2019/2020.
\end{abstract}

Kata kunci: hasil belajar, problem based learning, media audio visual, Bahasa Indonesia

Social, Humanities, and Education Studies (SHEs): Conference Series https://jurnal.uns.ac.id/shes

p-ISSN 2620-9284

e-ISSN 2620-9292 


\section{PENDAHULUAN}

Pada tanggal 2 Maret 2020 kasus covid-19 pertama kali diumumkan di Indonesia. Berbagai kebijakan telah dikeluarkan oleh Pemerintah Indonesia untuk mengurangi tingkat penyebaran virus covid-19, salah satunya dengan adanya Surat Edaran Kementerian Pendidikan dan Kebudayaan (Kemendikbud) Direktorat Pendidikan Tinggi No. 4 Tahun 2020 tentang pelaksanaan kebijakan pendidikan dalam masa darurat penyebaran corona virus desease (covid-19). Dalam surat edaran tersebut Kemendikbud menginstruksikan untuk menyelenggarakan pembelajaran jarak jauh dan menyarankan para peserta didik untuk belajar dari rumah masing-masing. Dampak dari pandemi covid-19 yakni pembelajaran masih akan terus dilakukan dari rumah masing-masing (study from home). Salah satu alternatif agar pembelajaran tetap berjalan yaitu dengan pembelajaran dalam jaringan (daring). Pembelajaran daring merupakan sistem pembelajaran yang dilakukan dengan tidak bertatap muka langsung, tetapi menggunakan platform yang dapat membantu proses belajar mengajar yang dilakukan meskipun jarak jauh. Tujuan dari adanya pembelajaran daring ialah memberikan layanan pembelajaran bermutu dalam jaringan yang bersifat masif dan terbuka untuk menjangkau peminat ruang belajar agar lebih banyak dan lebih luas (Sofyana \& Abdul, 2019:82). Oktafia \& Wulandari (2020) dalam penelitiannya menyimpulkan bahwa pembelajaran daring merupakan salah satu solusi untuk menerapkan social distancing guna mencegah mata rantai penyebaran wabah covid19.

Muatan pelajaran Bahasa Indonesia merupakan penunjang keberhasilan semua pelajaran. Jika siswa dapat berbahasa Indonesia dengan baik dan benar, siswa dapat mengkomunikasikan ide, pikiran secara lisan maupun tulisan dengan tepat. Hal tersebut dapat terwujud apabila siswa menguasai empat keterampilan berbahasa yang telah ditetapkan dalam kurikulum. Henry Guntur Tarigan (2008:2) menyatakan bahwa keterampilan berbahasa yang terdapat di dalam kurikulum mencakup empat segi, yaitu: keterampilan menyimak/mendengarkan (listening skill), keterampilan berbicara (speaking skill), keterampilan membaca (reading skill), dan keterampilan menulis (writing skill). Di dalam kurikulum 2013, muatan pelajaran Bahasa Indonesia tidak berdiri sendiri, melainkan secara tematik diajarkan bersama muatan pelajaran lainnya, seperti: PPKn, IPA, IPS, dan lain-lain.

Dalam situasi pandemi seperti saat ini, siswa diharuskan untuk belajar dari rumah. Guru sering mengalami kesulitan dalam menyajikan materi Bahasa Indonesia yang banyak itu dengan baik dan menarik. Buku-buku Bahasa Indonesia yang digunakan umumnya tebal dengan bahasa baku yang sulit dicerna membuat peserta didik mengalami kesulitan untuk melakukan kegiatan pembelajaran secara mandiri. Akibatnya, hasil belajar yang diperoleh peserta didik kelas V SD Negeri 01 Glandang pun tidak sesuai harapan karena belum mencapai KKM. Dalam proses pembelajarannya, respon peserta didik juga cenderung pasif ketika guru menyajikan materi. Rasa keingintahuan dan minat peserta didik untuk mempelajari materi Bahasa Indonesia masih rendah. Sebagai tenaga pendidik, guru berperan penting dalam menyajikan materi pelajaran agar peserta didik memiliki penguasaan pengetahuan dan dan keterampilan hidup yang dibutuhkan dalam kehidupan nyata. Hal tersebut dapat dilakukan melalui pembelajaran yang efektif. Pembelajaran adalah sebuah proses atau tindakan yang dirancang untuk memudahkan peserta didik dalam mengembangkan potensi yang dimiliki secara maksimal (Susanto, 2013). Guru tidak hanya melaksanakan langkah-langkah pembelajaran tetapi juga bertanggung jawab untuk membantu peserta didik dalam memahami materi pembelajaran sesuai dengan karakteristik peserta didik. Salah satu cara untuk memudahkan peserta didik dalam belajar adalah dengan memanfaatkan media pembelajaran.

Sanjaya (2010) mengemukakan bahwa media bukan hanya alat perantara seperti TV, radio, slide, bahkan cetakan, akan tetapi meliputi seseorang sebagai 
sumber belajar yang dikondisikan untuk memperoleh pengetahuan dan wawasan mengubah sikap seseorang serta menambah keterampilan. Media audio visual adalah gabungan dari dua media, yakni audio-visual atau pandang-dengar. Media audio visual dapat dijadikan pilihan dalam pembelajaran daring untuk meningkatkan semangat siswa dalam belajar karena sifatnya yang mudah dikemas, menarik dan menyenangkan. Dalam menggunakan media, tentunya juga perlu mempertimbangkan perkembangan teknologi terkini. Salah satu media yang dapat dimanfaatkan guru dalam proses pembelajaran adalah media PowerPoint. Melalui PowerPoint, guru dapat menampilkan teks, gambar dan video. Dalam penyampaiannya, guru memanfaatkan zoom agar siswa dapat menerima materi pelajaran dari rumah.

Disamping penggunaan media pembelajaran, diperlukan juga model pembelajaran yang tepat untuk menyampaikan materi kepada siswa, yang dapat membantu siswa untuk mengaitkan materi pelajaran dengan kehidupan nyata. Model pembelajaran PBL adalah pembelajaran yang menitik beratkan kepada peserta didik sebagai pembelajar serta terhadap permasalahan yang otentik atau relevan yang akan dipecahkan dengan menggunakan seluruh pengetahuan yang dimilikinya atau dari sumber-sumber lainnya (Lidnillah, 2013). Menurut Arends (2008:55), langkah-langkah dalam melaksanakan PBL ada 5 fase yaitu (1) mengorientasi siswa pada masalah; (2) mengorganisasi siswa untuk meneliti; (3) membantu investigasi mandiri dan berkelompok; (4) mengembangkan dan menyajikan hasil karya; (5) menganalisis dan mengevaluasi proses pemecahan masalah., permasalahan yang digunakan dalam PBL adalah permasalahan yang dihadapi di dunia nyata. Dalam upaya siswa memecahkan masalah, siswa akan memperoleh pengetahuan dan keterampilan baru. Guru tidak hanya menilai hasil belajar siswa tetapi juga menilai proses belajar yang dijalani siswa. Guru memantau perkembangan belajar siswa dalam mencapai tujuan pembelajaran, yakni membimbing dan mengarahkan siswa saat siswa berusaha memecahkan masalah sehingga siswa tetap berada pada alur yang tepat. Hasil penelitian Abdullah dan Ridwan (2008) menyatakan model PBL dapat meningkatkan hasil belajar siswa pada aspek kognitif, afektif dan psikomotorik.

\section{METODE}

Pendekatan yang digunakan dalam penelitian ini adalah penelitian kualitatif, yang berawal dari masalah yang ditemukan di lapangan, kemudian direfleksikan dan dianalisis berdasarkan teori yang menunjang kemudian dilakukan tindakan di lapangan. Jenis penelitian ini yaitu penelitian tindakan kelas (action research). Penelitian tindakan kelas merupakan penelitian yang dilakukan oleh guru di dalam kelasnya sendiri melalui refleksi diri dengan tujuan untuk memperbaiki kinerjanya sebagai guru sehingga kualitas proses dan hasil belajar siswa meningkat (Cresswell, 2008). Penelitian dilakukan di SD Negeri 01 Glandang Kabupaten Pemalang, waktu penelitian yaitu semester dua tahun pelajaran 2019/2020 yang dilaksanakan pada tanggal 31 Mei - 1 Juli 2020. Subjek penelitian yaitu siswa kelas V berjumlah 10 yang terdiri dari 5 laki-laki dan 5 perempuan. Teknik pengumpulan data menggunakan penilaian tertulis untuk memperoleh data hasil belajar Bahasa Indonesia berupa tes formatif melalui google form. Prosedur penelitian terdiri dari rencana (planning), pelaksanaan tindakan (action), pengamatan/observasi (observation) dan refleksi (reflection) (Cresswell, 2008). Data hasil dianalisis dengan presentase sederhana.

\section{HASIL DAN PEMBAHASAN}

Dari hasil penelitian yang telah dilakukan tentang Peningkatan Hasil Belajar Bahasa Indonesia Materi Iklan Melalui Model Problem Based Learning Berbantuan Media Audio Visual Pada Siswa Kelas V dapat diuraikan sebagai berikut. 


\section{Siklus I}

Pembelajaran berlangsung secara daring melalui zoom. Pada siklus I pembelajaran dilaksanakan dengan mengadakan tes formatif untuk mengetahui tingkat perkembangan peserta didik selama pembelajaran. Peserta didik mengerjakan tes formatif melalui google form. Siklus I membahas materi tentang iklan baris dan iklan kolom. Pembelajaran dilakukan dengan menerapkan model Problem Based Learning yang terdiri dari 5 langkah secara berurutan, yaitu: orientasi siswa pada masalah, mengorganisasi siswa, membimbing penyelidikan individual maupun kelompok, mengembangkan dan menyajikan hasil karya, menganalisis dan mengevaluasi. Hasil tes formatif peserta didik siklus I dapat dilihat pada tabel 1 berikut.

Tabel 1. Data Hasil Tes Formatif Siklus I

\begin{tabular}{ccc}
\hline Skor $(\mathbf{x})$ & $\mathbf{F}$ & FX \\
\hline $\mathbf{1 0 0}$ & 1 & 100 \\
$\mathbf{9 0}$ & 1 & 90 \\
$\mathbf{8 0}$ & 2 & 160 \\
$\mathbf{7 0}$ & 4 & 280 \\
$\mathbf{6 0}$ & 2 & 120 \\
$\mathbf{0 - 5 0}$ & - & 0 \\
\hline Jumlah & $\mathbf{1 0}$ & $\mathbf{7 5 0}$ \\
\hline
\end{tabular}

Tabel 1 menunjukkan bahwa setelah menempuh tahapan rencana dan pelaksanaan tindakan penelitian pada siklus I, terdapat 1 peserta didik yang mendapat nilai 100, 1 peserta didik yang mendapat nilai 90,2 peserta didik yang mendapat nilai 80,4 peserta didik yang mendapat nilai 70 , dan 2 peserta didik yang mendapat nilai 60 . Adapun KKM muatan pelajaran Bahasa Indonesia adalah $\geq 70$. Dengan demikian terdapat 7 peserta didik yang telah mencapai KKM dan 3 peserta didik yang belum mencapai KKM. Pada siklus I, ketuntasan belajar peserta didik meningkat menjadi $70 \%$ secara klasikal yang sebelumnya $60 \%$. Nilai tertinggi 100 dan nilai terendah 60 dengan nilai rata-rata kelas 75 .

Berdasarkan pelaksanaan kegiatan yang dilaksanakan pada siklus I, menghasilkan perubahan hasil belajar peserta didik namun ketuntasan hasil belajar peserta didik belum mencapai $100 \%$. Hal ini disebabkan beberapa faktor antara lain kekurangan guru dan peserta didik dalam menerapkan model pembelajaran dan kekurangan guru dalam mengelola kelas dan kekurangan guru dalam mengembangkan media pembelajaran. Oleh karena itu perolehan hasil belajar peserta didik pada siklus I menunjukkan bahwa masih ada tiga peserta didik yang mendapatkan nilai di bawah kriteria yang ditentukan, yaitu 70 maka tindakan dilanjutkan pada siklus II.

\section{Siklus II}

Pembelajaran berlangsung secara daring melalui zoom. Pada siklus II pembelajaran dilaksanakan dengan mengadakan tes formatif untuk mengetahui tingkat perkembangan peserta didik selama pembelajaran. Peserta didik mengerjakan tes formatif melalui google form. Siklus II membahas materi tentang unsur-unsur iklan. Pembelajaran dilakukan dengan menerapkan model Problem Based Learning yang terdiri dari 5 langkah secara berurutan, yaitu: orientasi siswa pada masalah, mengorganisasi siswa, membimbing penyelidikan individual maupun kelompok, mengembangkan dan menyajikan hasil karya, menganalisis dan mengevaluasi. Hasil tes formatif peserta didik siklus II dapat dilihat pada tabel 2 berikut. 
SHEs: Conference Series 3 (4) (2020) 244- 250

Tabel 2 Data Hasil Tes Formatif Siklus II

\begin{tabular}{ccc}
\hline Skor $(\mathbf{x})$ & $\mathbf{F}$ & Fx \\
\hline $\mathbf{1 0 0}$ & 1 & 100 \\
$\mathbf{9 0}$ & 2 & 180 \\
$\mathbf{8 0}$ & 4 & 320 \\
$\mathbf{7 0}$ & 2 & 140 \\
$\mathbf{6 0}$ & 1 & 60 \\
$\mathbf{0 - 5 0}$ & - & - \\
Jumlah & $\mathbf{1 0}$ & $\mathbf{8 0 0}$ \\
\hline
\end{tabular}

Tabel 2 menunjukkan terdapat 1 peserta didik yang mendapat nilai 100, 2 peserta didik yang mendapat nilai 90, 4 peserta didik mendapat nilai 80, 2 peserta didik mendapat nilai 70, 1 peserta didik mendapat nilai 60 . Adapun KKM muatan pelajaran Bahasa Indonesia adalah $\geq 70$. Dengan demikian terdapat 9 peserta didik yang telah mencapai KKM dan 1 peserta didik yang belum mencapai KKM. Setelah menempuh beberapa perbaikan dari hasil refleksi siklus I selanjutnya hasil belajar siswa pada siklus II meningkat dari $70 \%$ menjadi $90 \%$ secara klasikal. Nilai tertinggi 100 dan nilai terendah 60 dengan nilai rata-rata kelas 80 .

Berdasarkan pelaksanaan kegiatan yang dilaksanakan pada siklus II, menghasilkan perubahan hasil belajar siswa, namun ketuntasan belajar siswa belum mencapai $100 \%$. Setelah menempuh tahapan refleksi, ditemukan beberapa hal antara lain guru memperbaiki pembelajarannya dengan mendesain model pembelajaran PBL agar lebih menarik, misalnya penggunaan media pembelajaran yang bervariasi seperti media audio visual sehingga lebih dapat menarik minat siswa.

\section{Siklus III}

Pembelajaran berlangsung secara daring melalui zoom. Pada siklus III pembelajaran dilaksanakan dengan mengadakan tes formatif untuk mengetahui tingkat perkembangan peserta didik selama pembelajaran. Peserta didik mengerjakan tes formatif melalui google form. Pembelajaran dilakukan dengan menerapkan model Problem Based Learning yang terdiri dari 5 langkah secara berurutan, yaitu: orientasi siswa pada masalah, mengorganisasi siswa, membimbing penyelidikan individual maupun kelompok, mengembangkan dan menyajikan hasil karya, menganalisis dan mengevaluasi. Hasil tes formatif peserta didik siklus III dapat dilihat pada tabel 3 berikut.

Tabel 3 Data Hasil Tes Formatif Siklus III

\begin{tabular}{ccc}
\hline Skor $(\mathbf{x})$ & F & Fx \\
\hline 100 & 2 & 200 \\
90 & 2 & 180 \\
80 & 4 & 320 \\
70 & 2 & 140 \\
60 & - & - \\
$0-50$ & - & - \\
Jumlah & 10 & 840 \\
\hline
\end{tabular}

Tabel 3 menunjukkan terdapat 2 peserta didik yang mendapat nilai 100, 2 peserta didik yang mendapat nilai 90, 4 peserta didik mendapat nilai 80 dan 2 peserta didik mendapat nilai 70 . Adapun KKM muatan pelajaran Bahasa Indonesia adalah $\geq 70$. Dengan demikian terdapat seluruh peserta didik yang telah mencapai KKM. Setelah melakukan sejumlah perbaikan sebagaimana yang ditemukan pada kegiatan refleksi siklus II, ditemukan bahwa hasil belajar siswa pada siklus III meningkat dari $90 \%$ 
menjadi $100 \%$ secara klasikal. Hasil tersebut mengandung arti secara keseluruhan hasil belajar siswa dinyatakan tuntas sesuai dengan KKM yakni 70 dengan presentase $100 \%$ yang ditetapkan sekolah. Dengan demikian penelitian tindakan kelas ini dapat diakhiri pada siklus III.

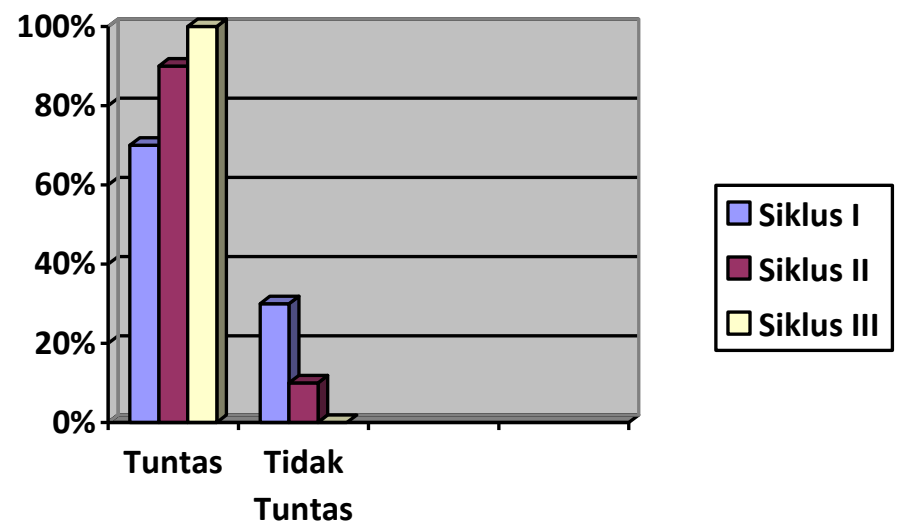

\section{Gambar 1. Perbandingan Hasil Belajar Peserta Didik Siklus I, II dan III}

Pada siklus I setelah diadakan tes kemampuan awal dilanjutkan dengan guru dan siswa menerapkan pembelajaran dengan model Problem Based Learning berbantu media audio visual, yang berlangsung secara daring melalui zoom. Setelah dilaksanakan siklus I dan dievaluasi dapat dilihat adanya peningkatan hasil belajar yaitu kondisi awal prosentase ketuntasan belajar siswa sebesar $60 \%$ sedangkan pada siklus I hasil belajar siswa mencapai 70\% dengan nilai tertinggi 100 dan nilai terendah 60 dengan nilai rata-rata kelas 75 . Oleh karena masih ditemukan ada tiga siswa yang belum tuntas, maka tindakan dilanjutkan dengan siklus II. Pada siklus II, terjadi peningkatan hasil belajar yakni ketuntasan mencapai $90 \%$ dengan nilai tertinggi 100 dan nilai terendah 60 serta nilai rata-rata kelas meningkat menjadi 80 . Tindakan dilanjutkan lagi ke siklus III dikarenakan masih ada siswa yang belum tuntas atau memenuhi kriteria ketuntuasan minimal (KKM). Pada siklus III, terjadi pula peningkatan hasil belajar karena secara keseluruhan siswa dinyatakan telah mencapai KKM 100\% dengan nilai tertinggi 100 dan nilai terendah 70 serta nilai rata-rata kelas 84 . Penerapan model Problem Based Learning dapat meningkatkan hasil belajar siswa. Hasil penelitian ini sesuai dengan penelitian sebelumnya yang dilakukan oleh Pasek (2016) bahwa penerapan model pembelajaran Problem Based Learning berbasis media gambar berpengaruh terhadap keterampilan membaca Bahasa Indonesia kelas V SD. Hasil penelitian ini juga sesuai dengan penelitian Patmawati (2018) terkait media audio visual, bahwa media audio visual efektif untuk meningkatkan hasil belajar siswa.

\section{SIMPULAN}

Berdasarkan hasil penelitian dan pembahasannya dapat disimpulkan bahwa melalui model Problem Based Learning berbantuan media audio visual dapat meningkatkan hasil belajar Bahasa Indonesia pada siswa kelas V SD Negeri 01 Glandang Kabupaten Pemalang tahun pelajaran 2019/2020. Peningkatan yang terjadi karena adanya kesan pembelajaran materi yang diajarkan melalui setiap permasalahan dan didukung dengan media audio visual yang menarik. Peserta didik menjadi teringat dengan materi dan dapat membentuk pengetahuannya sendiri. Berdasarkan penelitian yang telah dilaksanakan, model Problem Based Learning merupakan salah satu model pembelajaran yang harus dikuasai oleh guru. Guru juga 
perlu memanfaatkan media audio visual karena cocok digunakan dalam situasi pandemi seperti saat ini, yang mana peserta didik diharuskan untuk belajar dari rumah.

\section{DAFTAR PUSTAKA}

Abdullah, A.G dan Ridwan, T. (2008). "Implementasi PBL dalam Proses Pembelajaran di BPTP Bandung". Jurnal Penelitian Pendidikan. 5, (13), 1-10.

Andriani, M. R. (2016). Pengembangan Media Pembelajaran PowerPoint Interaktif Melalui Pendekatan Saintifik Untuk Pembelajaran Tematik Inegratif Siswa Kelas 2 SDN Bergas Kidul 03 Kabupaten Semarang. Scholaria, 144.

Arends, R. I. (2008). Belajar untuk mengajar. (Terjemahan Helly Prajitno Soetjipto \& Sri Mulyantini Soetjipto). New York: McGraw Hills. (Buku asli diterbitkan tahun 2007).

Cresswell, J. W. (2008). Education Research; Planning, Conducting, and Evaluating Quantitative and Qualitative Research (Third ed.). Amerika: Pearson Education Inc.

Kementrian Pendidikan dan Kebudayaan. 12 Maret 2020. Surat Edaran Nomor 3 Tahun 2020. Tentang Pencegahan COVID-19 pada Satuan Pendidikan.

Lidinillah, D. A. M. (2013). Pembelajaran Berbasis Masalah (Problem Based Learning). (Online), (http://file.upi.edu/Direktori/KDTASIKMALAYA/DINDIN_ABDUL_MUIZ_LIDINILLAH_\%28KDTASIKMALAYA\%29-197901132005011003/132313548\%20\%20dindin\%20abdul\%20muiz\%20lidinillah/Problem\%20Based\%20Learning.pdf), diakses 20 Juni 2020.

Oktafia \& Wulandari (2020). Pembelajaran Daring Sebagai Upaya Study From Home (SFH) Selama Pandemi Covid 19. Jurnal Pendidikan Administrasi Perkantoran (JPAP). Volume 8 Nomor 3, Halm 496-503.

Pasek, N.W.G.M., Abadi, I.B.G.S., Suara, I.M. (2016). Pengaruh Model Pembelajaran Problem Based Learning Berbasis Media Gambar Terhadap Keterampilan Membaca Pada Bahasa Indonesia. E-Journal PGSD Universitas Pendidikan Ganesha. Volume 4 Nomor 1, Halm 1-10.

Patmawati, D., Rustono, R., \& Halimah M. (2018). Pengaruh Media Audio Visual Terhadap Hasil Belajar Siswa Pada Materi Jenis-Jenis Pekerjaan di Sekolah Dasar. Jurnal IImiah Mahasiswa Pendidikan Guru Sekolah Dasar. Volume 5 Nomor 2, Halm 308-316.

Sanjaya, W. (2010). Perencanaan dan Desain Sistem Pembelajaran. Jakarta: Kencana.

Sofyana \& Abdul. (2019). Pembelajaran Daring Kombinasi Berbasis Whatsapp Pada Kelas Karyawan Prodi Teknik Informatika Universitas PGRI Madiun. Jurnal Nasional Pendidikan Teknik Informatika. Volume 8 Nomor 1, Halm. 81-86.

Susanto, A. (2013). Teori Belajar \& Pembelajaran di Sekolah Dasar. Jakarta: Kencana Prenada Media Group.

Tarigan, H. G. (2008). Menyimak Sebagai Suatu Keterampilan Berbahasa. Bandung: Angkasa. 